\title{
Serum S100B levels in patients with obstructive sleep apnea syndrome
}

\author{
Tıkayıcı uyku apne sendromlu hastalarda serum S100B düzeyleri
}

\author{
Gülfer Öztürk' ${ }^{1}$, Zeynep Giniş ${ }^{1}$, Berna Arlı², Şule Bilen², Gönül Erden ${ }^{1}$, Ersin Kasım Ulusoy², Cevdet Züngün ${ }^{3}$
}

\begin{abstract}
Objectives: Obstructive sleep apnea syndrome (OSAS) which is characterized by recurrent pharyngeal narrowing and breathing disturbances, can affect central neural system (CNS). S100B, which exerts neurotrophic and gliotrophic features, is a calcium binding protein. The aim of this study was to evaluate serum levels of S100B in patients with OSAS.
\end{abstract}

Materials and methods: Clinical and laboratory assessment were performed in 26 patients ( 5 women and 21 men) with OSAS and 28 (8 women and 20 men) age-, body mass index (BMI)- and sex- matched healthy subjects served as controls. The patients included in the study had whole-night polysomnography (PSG) performed in the sleep laboratory. Measurements of S100B were done using the commercially available ELISA kit.

Results: Patients and controls were well matched with regard to demographic characteristics. Serum S100B concentrations were $149.4 \pm 84.5 \mathrm{ng} / \mathrm{L}$ and $139.2 \pm 70.7$ $\mathrm{ng} / \mathrm{L}$ for patients with OSAS and control subject, respectively. There was no statistically significant difference in serum S100B concentrations between OSAS and control groups $(p>0.05)$.

Conclusions: Serum S100B protein level in serum did not significantly higher in patients with OSAS compared to the healthy subjects. However, further investigations are required, particularly in the area of biochemical markers of mild cerebral damage in patients with OSAS. J Clin Exp Invest 2012; 3 (3): 345-349

Key words: Obstructive sleep apnea syndrome, serum S100B, brain, polysomnography

\section{INTRODUCTION}

Sleep is natural part of human life. ${ }^{1}$ However, sleep disorder such as obstructive sleep apnea syndrome affect sleep quality and cause clinical symptoms which are mostly neuropsychiatric. ${ }^{2}$ Obstructive

\section{ÖZET}

Amaç: Tekrarlayan faringeal daralmalar ve nefes almada zorlukla karakterize olan obstrüktif uyku apne sendromu (OSAS) santral sinir sistemini etkileyebilir. Nörotrofik ve gliotrofik özellikler gösteren S100B kalsiyum bağlayıcı bir proteindir. Bu çalışmanın amacı, OSAS bulunan hastalarda serum S100B'nin düzeylerini araştırmaktır.

Gereç ve yöntem: Klinik ve laboratuvar değerlendirmeler için OSAS'lı 26 hasta (5 kadın ve 21 erkek)' çalışmaya dahil edildi. Yaş, cinsiyet ve vücut kitle indeksi uygun 28 (8 kadın ve 20 erkek) sağlıklı gönüllü kontrol grubu olarak alındı. Hastalara uyku laboratuvarında tüm gece polisomnografi uygulandı. Serum S100B ölçümü ticari bir ELISA kiti kullanılarak yapıldı.

Bulgular: Hasta ve sağlıklılar demografik özellikleri bakımından birbirleriyle uyumluydu. Serum S100B konsantrasyonları hastalar ve sağlıklı bireyler için sırasıyla, $149.4 \pm 84.5 \mathrm{ng} / \mathrm{L}$ ve $139.2 \pm 70.7 \mathrm{ng} / \mathrm{L}$ olarak bulundu. Obstrüktif uyku apne sendromu ve kontrol grubu arasında S100 B konsantrasyonlar bakımından anlamlı farklılık yoktu ( $p>0.05)$.

Sonuç: Serum S100B protein düzeyinde OSAS'lı hastalar kontrol grubu ile karşılaştıııldığında anlamlı fark bulunmadı. Daha sonraki çalışmalarla, OSAS'lı hastalarda özellikle küçük serebral hasarı gösteren biyokimyasal belirteçler alanında yapılacak ileri araştırmalara intiyaç vardır.

Anahtar kelimeler: Tıkayıcı uyku apne sendromu, serum S100B, beyin, polisomnografi

sleep apnea syndrome (OSAS) is very common disorder in adult population. ${ }^{3}$

Obstructive sleep apnea syndrome, which is defined by the occurrence of at least five obstructive apnea, hypopneas, or per hour during sleep, is characterized by recurrent pharyngeal narrowing

\footnotetext{
${ }^{1}$ Dışkapı Yıldırım Beyazıt Eğitim ve Araştırma Hastanesi, Klinik Biyokimya Bölümü, Ankara, Türkiye

${ }^{2}$ Ankara Numune Eğitim ve Araştırma Hastanesi, Nöroloji Kliniği, Ankara, Türkiye

${ }^{3}$ Ankara Numune Eğitim ve Araştırma Hastanesi, Klinik Biyokimya Bölümü, Ankara, Türkiye
}

Correspondence: Gülfer Öztürk,

Dışkapı Yıldırım Beyazıt Eğitim ve Araştırma Hastanesi, Klinik Biyokimya Bölümü, Ankara Email: gulfertabur@yahoo.com 
and breathing disturbances. ${ }^{4}$ The severity of OSAS is measured by apnea hypopnea index (AHI), which is classified three levels: mild ( $\mathrm{AHI}=5$ to 15 events per hour); moderate (AHI=15 to 30 events per hour); and severe (AHI=>30 events per hour). ${ }^{5}$

The repetitive hypoxia and reoxygenation cycle in OSAS is thought to resemble ischemia-reperfusion injury. ${ }^{6}$ The central neural system(CNS) is vulnerable to these hypoxic condition and neurocognitive manifestation of OSAS, which includes daytime sleepiness alteration in personality, impairment in concantretations, perception, communication, learning and memory. OSAS affect not only CNS3 but also other system such as the cardiovascular system, ${ }^{7}$ bone metabolism, ${ }^{8}$ the eyes ${ }^{9}$ and the endocrine system. ${ }^{10}$

S100B, which exerts neurotrophic and gliotrophic features, is a $21 \mathrm{kDa}$ calcium binding protein. It is produced and released mainly by astrocyte in CNS. ${ }^{11} \mathrm{~S} 100 \mathrm{~B}$ is also expressed in melanocytes, adipocytes, chondrocytes, and in smaller amounts in several other cell types both in the nervous system (e.g., some neuronal populations and microglia cell lines) and outside the nervous system (e.g., renal cells, myoblasts, skeletal muscle cells, skin Langerhans cells). ${ }^{12}$

The purpose of this study was to evaluate potential diagnostic utility of serum S100B in predicting brain damage caused by OSAS.

\section{MATERIALS AND METHODS}

\section{Subjects and ethics}

Clinical and laboratory assessment was performed in 26 patients ( 5 women and 21 men) with OSAS clinically evaluated. 28 ( 8 women and 20 men) age, body mass index (BMI)- and sex- matched healthy subjects served as controls.

We excluded subject with any of the following condition in this study: central sleep apnea; history of any cardiovascular, cerebrovascular, pulmonary disease, autoimmune disease, malignancy, migraine, thyroid disease, psychiatric disorder, renal failure, dysfunction of liver metabolism, acute infections, major surgery or trauma within one month. Subjects who participated in the study underwent a detailed cardiac and neurological examination. Subjects with risk factors for cardiovascular disease such as high total cholesterol and low density lipoprotein cholesterol and high triglyceride levels were also excluded from the study. Body mass index (BMI) was calculated as weight in kilograms divided by the square of height.
This study was approved by the local ethics committee of Ankara Diskapi Yildirim Beyazit Education and Research Hospital. The experiments were performed in accordance with the principles enumerated in the Helsinki Declaration of 1975. Informed consent was obtained from all subjects.

\section{Sleep analysis}

The patients included in the study had whole-night polysomnography (PSG) in the sleep laboratory. Their 4-channel electroencephalograms (EEG) were recorded with Alice 5 equipment. Electromyogram (EMG) was recorded bilaterally from anterior tibial muscles in order to determine leg movements. Chin EMG was also recorded. Nasal airflow was recorded with a nasal cannula. Abdominal and thorax movements, lying position, oxygen saturation, and electrocardiogram (ECG) were also recorded. The records obtained during the sleep study were scored manually according to AASM 2007 criteria by ENT specialists who had theoretical and practical education on sleep medicine and had their certificates.

\section{Measurement of S100B}

In the morning, blood samples were obtained from all patients and control subjects. The samples was centrifuged at $5000 \mathrm{Xg}$ for 10 minutes, the serum was separated and stored at $-80^{\circ} \mathrm{C}$ until assessment of S100B. Measurements of S100B were performed in an EPOCH system (USA) using the commercially available ELISA kit (Bio Vendor Research and Diagnostic Products, Czech Republic). Briefly, standards, quality controls and samples are incubated in microplate wells pre-coated with polyclonal anti-cow S100B antibody. After 120 minutes incubation and washing, biotin labeled monoclonal antihuman S100B antibody is added to the wells and incubated for 60 minutes with captured S100B. After another washing, Streptavidin- HRP Conjugate is added. After 30 minutes incubation and the last washing step, the remaining conjugate is allowed to react with the Substrate solution. The reaction is stopped by addition of acidic solution and absorbance of the resulting yellow product is measured. The absorbance is proportional to the concentration of S100B. A standard curve is constructed by plotting absorbance values against concentrations of Standards, and concentrations of unknown samples are determined using this standard curve. S100B levels are expressed as $\mathrm{ng} / \mathrm{L}$ (mean \pm SD). The samples were carried out together in the same experiment. Intra-assay and the inter-assay variation coefficients were $3.8 \%$ and $5.2 \%$, respectively. 
The assay range of the S100B protein, ELISA kit was $50-2000 \mathrm{ng} / \mathrm{L}$, The samples were carried out together in the same experiment.

\section{Statistical Analysis}

Results were presented as means plus minus standard deviation. Data were analyzed by using a commercially available statistics software package (SPSS vs. 17). Data normality was assessed using the Kolmogorov-Smirnov test. To compare variables between OSAS and control groups we performed Student's t-test for normally distributed variables, Mann-Whitney's U-test when the distribution was skewed. Categorical data were analyzed by $\mathrm{X}^{2}$ test. Statistical significance was considered for $p<0.05$.

\section{RESULTS}

The characteristics of the patient and control groups are listed in Table 1. Patients and controls were well matched with regard to demographic characteristics. Data were normally distributed for patient age, BMI and S100B. Data of sleep analyze in patients with OSAS are shown in Table 2. S100B concentrations were similar in both study groups.

Table 1.Charecteristic of obstructive sleep apnea syndrome (OSAS) and control subjects ${ }^{\text {a }}$

\begin{tabular}{lccc}
\hline Variable & $\begin{array}{c}\text { OSAS } \\
(\mathrm{n}=26)\end{array}$ & $\begin{array}{c}\text { Control } \\
(\mathrm{n}=28)\end{array}$ & $p^{\mathrm{b}}$ \\
\hline Age (years) & $56 \pm 10$ & $56 \pm 11$ & 0.995 \\
$\begin{array}{l}\text { Body mass index } \\
\left(\mathrm{kg} / \mathrm{m}^{2}\right)\end{array}$ & $28.8 \pm 3.1$ & $27.7 \pm 2.5$ & 0.135 \\
Gender (M/F) & $21 / 5$ & $20 / 8$ & 0.422 \\
S100B (ng/L) & $149.42 \pm 84.53$ & $139.16 \pm 70.73$ & 0.630 \\
\hline
\end{tabular}

a Data are given as mean \pm SD or number

${ }^{b} t$-Test for continuous variables and $\mathrm{X}^{2}$-test for categorical variables.

Table 2. Data of sleep analyze in patients with obstructive sleep apnea syndrome (OSAS) (mean \pm SD)

\begin{tabular}{ll}
\hline Variable & OSAS $(\mathrm{n}=26)$ \\
\hline Time asleep (min) & $356 \pm 48$ \\
AHI (event/hour) & $51 \pm 39$ \\
Lowest oxygen saturation $(\%)$ & $76 \pm 8$ \\
\hline
\end{tabular}

AHI: Apnea-Hipopnea Index

\section{DISCUSSION}

Epidemiological studies showed that OSAS had a high frequency in general population with a prevalence of $2-4 \%{ }^{13}$
Some cerebrospinal fluid (CSF) markers, including S-100B protein, may serve as sensitive markers of the extension of brain damage. CSF concentrations of S100B protein have positively correlated with serum concentrations of S100B protein in traumatic brain injury. ${ }^{14}$ However, a lumbar puncture is an invasive procedure which must be performed by an experienced doctor. For these reasons, in serum, a biochemical marker indicating cerebral damage would be of benefit in patients with OSAS.

Repeated apnoeic episodes during sleep in patients with OSAS may lead to changes in cerebral metabolism. Hypoxic brain damage and fragmentation of sleep are generally thought to be causes of excessive daytime sleepiness, emotion and cognitive deficiencies. ${ }^{15}$ The evidence that intermittent hypoxia is associated with increased oxidative stress is based on findings from cell culture studies and animal models, and from controlled studies in humans. ${ }^{6}$ Neurons are particularly susceptible to oxidative damage as brain is enriched with polyunsaturated fatty acids. ${ }^{16,17}$ The nervous system also has low level of defense repair mechanisms and very high oxygen consumption against oxidative injury. ${ }^{18}$ It has been showed that astrocytes respond to intermittent hypoxia exposure with reactive gliosis after only one day of intermittent hypoxia exposure in rats. ${ }^{3}$ The glial protein S100B is secreted by reactive astrocytes ${ }^{19}$ Reactive astrogliosis, increased S100B levels. ${ }^{3}$ S100B level in serum can increase not only glial damage but also solely by opening of the blood brain barrier. ${ }^{20}$

S100B's effect is depend on its concentration inducing neuronal survival or death. In a low concentration of S100B has a potent effect on neuritis extension and enhances neuronal survival after injury ${ }^{21}$ while in the high concentration, S100B has been shown to exert neurotoxic effects. ${ }^{22}$

Obstructive sleep apnea syndrome might be an important risk factor for stroke. ${ }^{23}$ Brouns et al. ${ }^{24}$ have analyzed S100B concentrations in CSF of acute ischemic stroke patients and control subjects. In the recent study, S100B concentrations were similar in both groups. However, S100B correlated with stroke severity and outcome.

In line with some previous studies ${ }^{25,26}$ showed that serum S100B level of patients with OSAS was significantly higher than control group. Jordan et al. ${ }^{27}$ have also investigated biochemical markers, including NSE, S100B and beta-trace proteins, of brain damage in OSAS patients just before and after sleep. However, their results were showed that no difference between controls and patients. Simi- 
larly, in this study serum S100B levels were not statistically higher in the OSAS group compared to the control group.

Ethnicity is an important contributing factor in sleep disordered breathing. ${ }^{28}$ In addition to this, older patients are more likely to suffer brain damage due to OSAS than are younger people. ${ }^{29}$ Therefore, it has been shown that a negative correlation between blood S100B and age in the first 20 years of life; after age 20, S100B has not appear to vary with age. ${ }^{30}$

These different results could be explained by the ethnic difference, medications, cerebral areas affected or characteristics of population. ${ }^{5}$

In conclusion, in our study, S100B protein level in serum did not significantly higher in patients with OSAS compared to the control group. However, further investigations are required, particularly in the area of biochemical markers of small cerebral damage in patients with OSAS, to monitor progression and efficacy.

\section{Conflict of interest statement}

The authors declare that there are no conflicts of interest.

\section{REFERENCES}

1. Yun $\mathrm{CH}$, Jung $\mathrm{KH}$, Chu $\mathrm{K}$, et al. Increased circulating endothelial microparticles and carotid atherosclerosis in obstructive sleep apnea. J Clin Neurol 2010;6(2):8998.

2. Flemons WW. Clinical practice. Obstructive sleep apnea. N Engl J Med 2002;347(7):498-504.

3. Aviles-Reyes RX, Angelo MF, Villarreal A, et al. Intermittent hypoxia during sleep induces reactive gliosis and limited neuronal death in rats: implications for sleep apnea. J Neurochem 2010;112(4):854-69.

4. Isono S. Obesity and obstructive sleep apnoea: mechanisms for increased collapsibility of the passive pharyngeal airway. Respirology 2012;17(1):32-42.

5. da Silva LG, Mottin CC, Souza DO, Portela LV, et al. Serum S100B but not NSE levels are increased in morbidly obese individuals affected by obstructive sleep apnea-hypopnea syndrome. Obes Surg 2008;18(8):993-9.

6. Kohler M, Stradling JR. Mechanisms of vascular damage in obstructive sleep apnea. Nat Rev Cardiol 2010;7(12):677-85.

7. Ziegler MG, Milic M, Elayan H. Cardiovascular Regulation in Obstructive Sleep Apnea. Drug Discov Today Dis Models 2011;8(4):155-60.

8. Uzkeser $\mathrm{H}$, Yildirim K, Aktan B, et al. Bone mineral density in patients with obstructive sleep apnea syndrome. Sleep Breath April 2012 (Epub-In press).
9. Campos-Rodriguez F, Fernandez-Palacin A, ReyesNunez N, Reina-Gonzalez A. [Clinical and polysomnographic features of rapid-eye-movement-specific sleep-disordered breathing]. Arch Bronconeumol 2009;45(7):330-4.

10. Calvin AD, Albuquerque FN, Lopez-Jimenez F, Somers VK. Obstructive sleep apnea, inflammation, and the metabolic syndrome. Metab Syndr Relat Disor 2009;7(4):271-8.

11. Donato R. Intracellular and extracellular roles of S100 proteins. Microsc Res Tech 2003;60(6):540-51.

12. Sorci G, Riuzzi F, Agneletti AL, Marchetti C, Donato $R$. S100B causes apoptosis in a myoblast cell line in a RAGE-independent manner. J Cell Physiol 2004;199(2):274-83.

13. Ferini-Strambi L, Fantini ML. Cerebrovascular diseases and sleep-disordered breathing. Clin Exp Hypertens 2006;28(3-4):225-31.

14. Bellander BM, Olafsson IH, Ghatan PH, et al. Secondary insults following traumatic brain injury enhance complement activation in the human brain and release of the tissue damage marker S100B. Acta Neurochir (Wien) 2011;153(1):90-100.

15. Sharma SK, Sinha S, Danishad KA, et al. Proton magnetic resonance spectroscopy of brain in obstructive sleep apnoea in north Indian Asian subjects. Indian J Med Res 2010;132:278-86.

16. Akyol O, Herken $\mathrm{H}, \mathrm{Uz} \mathrm{E}$, et al. The indices of endogenous oxidative and antioxidative processes in plasma from schizophrenic patients. The possible role of oxidant/antioxidant imbalance. Prog Neuropsychopharmacol Biol Psychiatry 2002;26(5):995-1005.

17. Ozturk E, Demirbilek S, Kadir But A, Saricicek V, Gulec M, Akyol O, et al. Antioxidant properties of propofol and erythropoietin after closed head injury in rats. Prog Neuropsychopharmacol Biol Psychiatry 2005;29(6):922-7.

18. Fadillioglu E, Gursul C, Iraz M. Effects of caffeic acid phenethyl ester on thioacetamide-induced hepatic encephalopathy in rats. Prog Neuropsychopharmacol Biol Psychiatry 2010;34(8):1440-5.

19. Davey GE, Murmann P, Heizmann CW. Intracellular $\mathrm{Ca}^{2+}$ and $\mathrm{Zn}^{2+}$ levels regulate the alternative cell density-dependent secretion of S100B in human glioblastoma cells. J Biol Chem 2001;276(33):30819-26.

20. Marchi N, Cavaglia M, Fazio V, Bhudia S, Hallene K, Janigro D. Peripheral markers of blood-brain barrier damage. Clin Chim Acta 2004;342(1-2):1-12.

21. Huttunen HJ, Kuja-Panula J, Sorci G, Agneletti AL, Donato $\mathrm{R}$, Rauvala $\mathrm{H}$. Coregulation of neurite outgrowth and cell survival by amphoterin and $\mathrm{S} 100$ proteins through receptor for advanced glycation end products (RAGE) activation. J Biol Chem 2000;275(51):40096105.

22. Gerlach R, Demel G, Konig HG, Gross U, Prehn $\mathrm{JH}$, Raabe A, et al. Active secretion of S100B from astrocytes during metabolic stress. Neuroscience 2006;141(4):1697-701. 
23. Yaggi HK, Concato J, Kernan WN, Lichtman JH, Brass LM, Mohsenin V. Obstructive sleep apnea as a risk factor for stroke and death. $\mathrm{N}$ Engl $\mathrm{J}$ Med 2005;353(19):2034-41.

24. Brouns R, De Vil B, Cras P, De Surgeloose D, Marien $P$, De Deyn PP. Neurobiochemical markers of brain damage in cerebrospinal fluid of acute ischemic stroke patients. Clin Chem 2010;56(3):451-8.

25. Feng $H F X$, Jiang $H$. The changes of memory and their correlations to S100beta protein as well as neuron-specific enolase in patients with obstructive sleep apnea-hypopnea syndrome. Lin Chung Er Bi Yan Hou Tou Jing Wai Ke Za Zhi 2011;25(3):105-8.

26. Braga CW, Martinez D, Wofchuk S, Portela LV, Souza DO. S100B and NSE serum levels in obstructive sleep apnea syndrome. Sleep Med 2006;7(5):431-5.
27. Jordan W, Hagedohm J, Wiltfang J, et al. Biochemical markers of cerebrovascular injury in sleep apnoea syndrome. Eur Respir J 2002;20(1):158-64.

28. Ong KC, Clerk AA. Comparison of the severity of sleep-disordered breathing in Asian and Caucasian patients seen at a sleep disorders center. Respir Med 1998;92(6):843-8.

29. Sonka K, Kelemen J, Kemlink D, et al. Evening and morning plasma levels of protein S100B in patients with obstructive sleep apnea. Neuro Endocrinol Lett 2007;28(5):575-9.

30. Portela LV, Tort AB, Schaf DV, et al. The serum S100B concentration is age dependent. Clin Chem 2002;48(6 Pt 1):950-2. 